\title{
KERAGAAN TEKNIS DAN ASPEK BIOLOGI PENANGKAPAN MADIDIHANG MENGGUNAKAN RUMPON DI PERAIRAN KAUR, BENGKULU
}

\section{STUDY OF BIOLOGY AND TECHNICAL ASPECTS OF MADIDIHANG USING FADS IN KAUR WATERS, BENGKULU)}

\author{
Ali Muqsit ${ }^{1}$, Roza Yusfiandayani², Mulyono S. Baskoro ${ }^{2}$ \\ ${ }^{1}$ Program Studi Teknologi Perikanan Laut, Sekolah Pascasarjana \\ ${ }^{2}$ Departemen Pemanfaatan Sumberdaya Perikanan, \\ Fakultas Perikanan dan Ilmu Kelautan, Institut Pertanian Bogor \\ Korespondensi: alimuqsit@gmail.com,ochaipb@gmail.com, baskoro.mul@gmail.com
}

\begin{abstract}
The development of fisheries in the consisting area from various aspects, one of them from the biological aspect. The biological aspects has important effort for fisheries development in the area. Biological aspects for this research is useful to know composition of gastric yellowfin tuna that landed on Pasar Lama. A total of 30 sampled gastric yellowfin tuna taken on September 2015 to January 2016 from a fisherman at the Pasar Lama for the measurement of the total-length, total-weight, length-weight correlation analysis, and analysis of the gastric with frequency of occurrence method, volume organism method and preponderance index. The data has been calculated between correlation from total-length and total-weight of yellow fin tuna was positive allometric with b values is 4.22. The result from preponderance index calculation of squid is $81.77 \%$. Based on the conclusion, squid is main food for yellow fin tuna in Pasar Lama Kaur and based on the length-weight correlation analysis is allometric positive results obtained in which the growth of yellow fin tuna weight faster than the growth of length.
\end{abstract}

Keyword: biology aspects, Kaur waters, stomach content, yellowfin tuna

\begin{abstract}
ABSTRAK
Pengembangan suatu perikanan tangkap di suatu daerah terdiri dari berbagai aspek, salah satunya dilihat dari aspek biologi. Adanya aspek biologi memiliki arti penting sebagai upaya untuk pengembangan perikanan suatu daerah. Dalam penelitian ini aspek biologi berguna untuk mengetahui komposisi isi lambung ikan tuna sirip kuning yang didaratkan di Pasar Lama. Sebanyak 30 ekor sampel lambung ikan tuna sirip kuning yang diambil pada bulan September 2015Januari 2016 dari pengepul tuna di pasar lama untuk selanjutnya dilakukan pengukuran panjang total, berat tubuh, analisis hubungan panjang berat, serta analisis isi lambung dengan metode frekuensi kejadian, metode volumetrik, dan index prepoderance. Data yang telah dihitung antara hubungan panjang total ikan dengan berat tubuh semua ikan tuna sirip kuning bersifat allometrik positif dengan nilai b sebesar 4,22. Hasil yang didapatkan dari dari semua perhitungan indeks preponderance organisme cumi-cumi sebesar 81,77\%. Berdasarkan hasil penelitian diperoleh kesimpulan, cumicumi merupakan makanan utama bagi ikan tuna sirip kuning di wilayah Pasar Lama Kaur dan berdasarkan hubungan panjang berat didapatkan hasil bersifat allometrik positif dimana pertumbuhan bobot ikan tuna sirip kuning lebih cepat dibanding pertumbuhan panjang.
\end{abstract}

Kata kunci: Aspek biologi, isi lambung, perairan Kaur, yellowfin tuna 


\section{PENDAHULUAN}

\section{Latar belakang}

Indonesia memiliki 5 jenis ikan tuna yang secara komersial di perjual belikan baik untuk konsumsi lokal maupun untuk pasar internasional. Kelima jenis itu adalah tuna sirip kuning (Thunnus albacares), tuna mata besar atau bigeye tuna ( $T$. obesus), albakora atau albacore ( $T$. alalunga), cakalang atau skipjack (Katsuwonus pelamis) dan tuna sirip biru selatan Southern bluefin tuna ( $T$. maccoyii). Berdasarkan data sejarah yang dimiliki, ikan tuna ditangkap berdasarkan 3 cara penangkapan yaitu: purse seine, long line dan pole and line (Rawlinson et al 1992). Kapal-kapal purse seine terutama menangkap ikan cakalang dan ikan tuna sirip kuning dengan target menangkap ikan yang berenang di permukaan baik yang berenang dipermukaan atau yang bergerombol disekitar rumpon. Kapal-kapal purse seine menangkap di sekitar rumpon yang dibuat sedemikian rupa dari bahan bahan alami seperti kayu terapung, pelampung dan tali jangkar dengan cara penempatan menetap dan atau dihanyutkan. Perikanan long line menangkap pada kedalaman tertentu dengan target tuna sirip biru selatan, albacore, tuna mata besar dan tuna sirip kuning (ISSF 2014a). Perikanan huhate menangkap tuna sejenis cakalang dan juga ikan tuna sirip kuning (ISSF 2009; ISSF 2014b).

Sampai ditahun 60an, armada perikanan pole and line mendominasi penangkapan ikan tuna dan cakalang, namun demikian pada saat ini perikanan pole and line hanya tinggal beroperasi sekitar $10 \%$ dari total tangkapan dunia (ISSF 2009; ISSF 2014b). Jepang, Maladewa dan Indonesia menduduki tiga besar produsen cakalang dari perikanan pole and line (IPNLF 2012) dengan tujuan pemasarannya adalah ke Eropa, USA and Jepang (Stone et al. 2009). Tahun 2011, ikan tuna sirip kuning yang tertangkap adalah sekitar 479.000 ton, $12 \%$ turun dari tahun 2010 tuna sirip kuning ditangkap terutama oleh purse seine, diperkirakan sebesar $56 \%$ dari total tangkapan, namun sekitar $20 \%$ ditangkap oleh alat penangkapan ikan lainnya di Philippina dan Indonesia.

Secara astronomis Kabupaten Kaur terletak antara $103^{\circ} 4^{\prime} 8,76^{\prime \prime}-103^{\circ} 46^{\prime} 50,12^{\prime \prime}$ BT dan $4^{\circ} 15^{\prime} 8,21^{\prime \prime}-4^{\circ} 55^{\prime} 27,77^{\prime \prime}$ LS. Provinsi Begkulu memiliki potensi yang cukup tinggi dari sektor perikanan laut sebesar 52.295 ton pada tahun 2012. Produksi perikanan laut dari Kabupaten Kaur pada tahun 2012 sebesar 1448 ton. Hasil dari sektor perikanan daerah ini berupa berlimpahnya sumberdaya gurita dan ikan-ikan ekonomis penting, seperti tuna sirip kuning (Thunnus albacares), tongkol, cakalang dan ikan lainnya. Nelayan di Kaur menggunakan alat tangkap berupa pancing, pukat, jaring, perangkap dan beberapa alat tangkap lainnya (BPS 2013).

Nelayan Kaur umumnya menangkap ikan-ikan pelagis dengan alat tangkap jaring dan pancing (pancing boya) serta menggunakan alat bantu penangkapan lainnya berupa rumpon. Umumnya para nelayan masih memiliki keterbatasan teknologi penangkapan serta alat tangkap yang sederhana, wilayah operasinya semakin terbatas, hanya di sekitar perairan pantai. Ketergantungan nelayan pancing boya terhadap musim masih sangat tinggi, sehingga nelayan tidak pergi kelaut untuk menangkap ikan pada saat musim ombak besar, terutama musim angin barat (bulan Oktober, November, Desember dan Januari). Hal ini biasa berlangsung sampai lebih dari satu bulan. Akibatnya, selain hasil tangkapan yang berkurang karena keterbatasan alat tangkap yang dimiliki, juga pada musim angin barat tidak dapat menangkap ikan secara maksimal. Kondisi kekurangan seperti ini sering dialami para nelayan, pendapatan yang diperoleh pada saat menangkap ikan habis dikonsumsi pada saat paceklik (Mulyadi 2007).

Kebiasaan makanan, menurut Gunarso (1985) adalah makanan yang dimakan ikan mencakup jenis dan jumlah makanan. Kebiasaan makanan ikan dipengaruhi oleh beberapa faktor antara lain habitat hidup, kesukaan terhadap jenis makanan tertentu, musim, ukuran, dan umur ikan (Lagler 1956). Effendie (2002) menyatakan faktor-faktor yang menentukan suatu spesies ikan akan memakan jenis organisme makanan adalah ketersediaan makanan, ukuran makanan, warna, rasa, tekstur, dan selera ikan terhadap makanan. Ikan tuna sirip kuning biasanya dalam mencari makan membentuk schooling atau bergerombol. Makanan ikan tuna sirip kuning biasanya berupa ikan-ikan kecil, cephalopoda, dan crustacea. Salah satu daerah yang memiliki potensi sumberdaya ikan tuna sirip kuning adalah Samudera Hindia. Makanan merupakan faktor yang menentukan bagi populasi, pertumbuhan dan kondisi ikan (Effendie 1979). Kebutuhan makanan ikan diperairan sudah tersedia yaitu berupa makanan alami, baik berupa hewan (zooplankton, invertebrata, dan vertebrata), tumbuhan (fitoplankton dan tumbuhan air), dan organisme mati (detritus). Selain itu, organisme yang dapat menjadi makan ikan tersebut tergantung pada tropik level (Sjafei et al. 1989).

Studi makanan dapat memperlihatkan secara mendetail hubungan ekologis 
diantara organisme, sehingga diperlukan identifikasi secara menyeluruh dari jenisjenis makanan tersebut. Organisme hidup berinteraksi satu dengan yang lain dan dengan lingkungan abiotik, tidak ada organisme hidup bebas dari lingkungan. Komposisi dari makanan ikan akan membantu menjelaskan kemungkinan habitat yang dikunjungi (Lagler 1956; Kagawade 1967; Holden \& Raitt 1974). Tujuan dari tulisan ini adalah untuk: Mengetahui keragaan teknis penangkapan ikan tuna madidihang di sekitar rumpon perairan Kaur; Menganalisis komposisi isi lambung dan hubungan panjang berat ikan tuna madidihang di sekitar rumpon perairan Kaur.

\section{METODE PENELITIAN}

Bahan dan alat yang digunakan dalam penelitian ini adalah ikan tuna sirip kuning (Thunnus albacares) yang diperoleh dari hasil tangkapan langsung di perairan Kabupaten Kaur Bengkulu (Gambar 1). Alat tangkap pancing boya, meteran gulung, GPS, gelas ukur.

Data hubungan panjang berat diperoleh 2 cara yaitu menggunakan data primer yang diambil pada bulan September 2015-Januari 2016 sebanyak 30 ekor, dengan panjang total berkisar 94-61 cm dan berat berkisar dari 13-90 kg, dan data sekunder (data stastistik hasil tangkapan di TPI) selama Januari 2015-Agustus 2015. Pertama kali yang diukur dari beberapa sampel tersebut ialah panjang dan berat dari ikan tuna sirip kuning tersebut. Panjang total ikan atau biasa disebut total length diukur dari bagian terdepan moncong ikan hingga bagian ujung ekor ikan. Berat ikan diukur dengan timbangan $\mathrm{kg}$.

Ikan hasil tangkapan yang didaratkan di TPI ikan langsung di proses dan bagian isi perut diawetkan dengan formalin $10 \%$ dan dibawa ke laboratorium untuk diamati isi lambung. Isi lambung tersebut kemudian dipilah-pilah perjenis organisme yang ada didalamnya dan kemudian dianalisis dengan metode frekuensi kejadian, metode volumetrik dan indeks preponderance (IP).

\section{Hubungan panjang berat}

Menurut Effendie (1997) menyatakan bahwa hubungan antara panjang berat dapat dihitung berdasarkan persamaan :

$$
W=a L^{b}
$$

Keterangan

$\mathrm{W}=$ Berat (gram)
$\mathrm{L}=$ Panjang $(\mathrm{mm})$

$\mathrm{a}=$ Intersep (perpotongan kurva hubungan panjang berat dengan sumbu y)

$\mathrm{b}=$ Pendugaan koefisien hubungan panjang berat

Untuk mengetahui konstatakonstanta tersebut, persamaan terebut perlu ditransformasi menjadi bentuk log, sehingga menjadi:

$\log W=\log \left(a \cdot L^{b}\right)$

$\log W=\log a+\log L^{b}$

$\log W=\log a+b \log L$

Untuk mendapatkan parameter a dan $\mathrm{b}$, digunakan analisis regresi dengan Log W sebagai 'y' dan Log L sebagai 'x', maka didapatkan persamaan regresi:

$$
y=a+b x
$$

Hasil dari perhitungan hubungan panjang-berat, lalu diintepretasikan. Bilamananilaibsamadengan 3 menunjukkan bahwa pertumbuhan ikan tidak berubah bentuknya. Pertambahan panjang ikan seimbang dengan pertambahanberatnya. Pertumbuhan demikian merupakan pertumbuhan isometrik. Sedangkan apabila $\mathrm{n}$ lebih besar atau lebih kecil dari 3 dinamakan pertumbuhan allometrik. Apabila harga $b$ kurang dari 3 menunjukkan keadaan ikan yang kurus dimana pertambahan panjangnya lebih cepat dari pertambahan beratnya. Apabila harga $b$ lebih besar dari 3 menunjukkan ikan itu montok, pertambahan berat lebih cepat dari pertambahan panjangnya (Effendie 1997). Lebih lanjut menurut (Afiati 2005), kesimpulan dari nilai yang diperoleh divalidasi menggunakan uji statistik sederhana dengan selang kepercayaan 95\%, untuk mengetahui penyimpangan dari pola pertumbuhan isometrik atas variabelvariable yang diperbandingkan, sebagai berikut :

Hipotesis:

Ho terima $=$ tidak berbeda nyata $(\mathrm{p}>0,05)$

Ho tolak = berbeda nyata $(\mathrm{p}<0,05)$

$$
\text { tobs }(n-1) d f=\frac{(b-\beta)}{S \text { erordari } b}
$$

Keterangan :

tobs $=$ t hitung

$\mathrm{b}=$ nilai $\mathrm{b}$ yang didapat dari hasil regresi

$\beta=$ nilai koefisien panjang-berat (3)

$\mathrm{S}$ error $=$ standar eror

Keeratan hubungan antara panjang dan berat ikan ditunjukkan oleh koefisien 
korelasi (r) yang diperoleh. Nilai r mendekati 1 menunjukkan hubungan antara dua peubah tersebut kuat dan terdapat korelasi yang tinggi, akan tetapi apabila r mendekati 0 maka hubungan keduanya sangat lemah atau hamper tidak ada (Walpole 1995).

\section{Metode frekuensi kejadian}

Menurut Taunay (2012) cara mengukur frekuensi kejadian dengan mencatat tiaptiap isi lambung ikan sehingga isi lambung terbagi menjadi dua golongan yaitu lambung berisi dan lambung kosong, dengan rumus:

Dimana :

$$
F K=\frac{N I}{I} X 100 \%
$$

$$
\begin{array}{ll}
\mathrm{FK} & =\text { Frekuensi kejadian } \\
\mathrm{Ni} & =\text { Jumlah total satu jenis organisme } \\
\mathrm{I} & =\text { Total lambung berisi }
\end{array}
$$

\section{Metode volumetrik}

Metode volumetrik adalah salah satu metode yang bertujuan untuk mengukur makan ikan berdasarkan volume makanan yang terdapat di dalam lambung ikan.

$$
\% \text { Volume }=\frac{\% i}{I} \times 100 \%
$$

$\% \mathrm{i}=$ Volume total satu macam organisme dalam persen

I =Total lambung yang berisi

\section{Indeks preponderance}

Indeks preponderance merupakan perhitungan yang digunakan untuk mengevaluasi kebiasaan makan ikan dengan gabungan dari dua metode antara lain metode frekuensi kejadian dan metode volumetrik. Persamaan rumus index preponderance berdasarkan Effendie (1979), sebagai berikut:

$$
I i=\frac{V i \times O i}{\sum V i \times O i} \times 100 \%
$$

Keterangan :

$\mathrm{Vi}=$ persentase volume satu macam makanan

Oi = persentase frekuensi kejadian satu macam makanan

¿vi Oi= jumlah Vi x Oi dari semua macam makanan

Ii = Index of Preoponderance

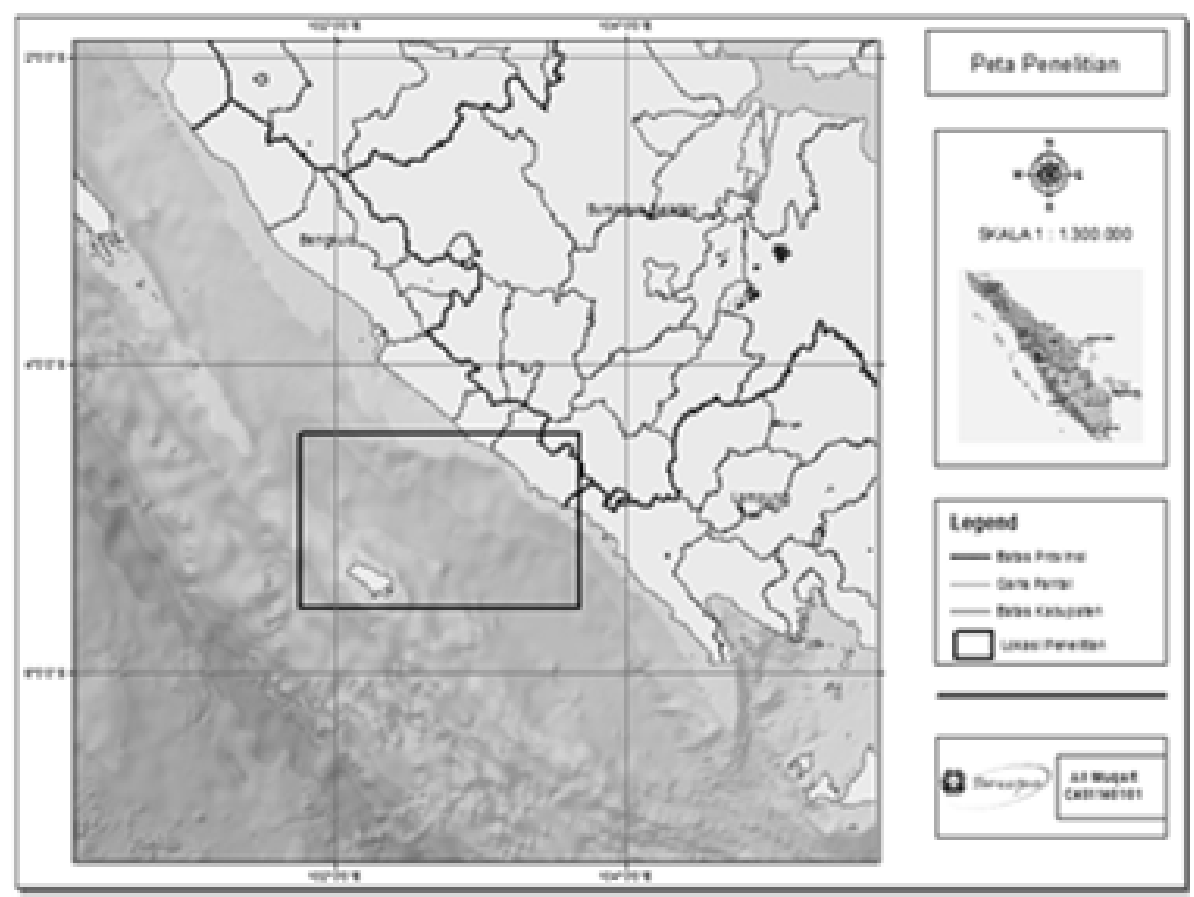

Gambar 1. Lokasi penelitian 


\section{HASIL DAN PEMBAHASAN}

\section{Keragaan teknis}

Kedalaman

perairan

lokasi pemasangan, rumpon digolongkan menjadi 2 (dua) kategori yaitu; rumpon laut dangkal yang dipasang di perairan pada kedalaman antara 30-75 meter, dan rumpon laut dalam yang dipasang pada perairan dengan kedalaman lebih dari $200 \mathrm{~m}$ (Subani dan Barus 1989). Rumpon di perairan Kaur mulai dari jarak 16-50 mil ke arah barat dan kebanyakan berada pada jarak 3040 mil dari pantai yaitu pada kedalaman perairan 700-900 meter adapun konstruksi rumpon seperti pada Gambar 2. Nelayan dalam menempatkan rumpon biasanya tidak memperhatikan faktor jarak antar rumpon. Berdasarkan Keputusan Menteri Kelautan dan Perikanan Nomor 26 tahun 2014, tentang Pemasangan dan Pemanfaatan Rumpon, bahwa jarak antar rumpon 10 mil. Bahkan sebelum adanya UU perikanan yang mengatur jarak pemasangan rumpon, di perairan Kaur rumpon hanya 1.60 mil dari pantai dan jarak antar rumpon lebih kurang hanya 3 mil.

Rumpon yang berada di perairan Kaur bukanlah milik pribadi atau kelompok nelayan setempat, rumpon tersebut merupakan rumpon milik kapal pukat cincin dari Jakarta yang beroperasi di perairan Kaur, dalam pengoperasian nelayan Kaur juga memanfaaatkan untuk menangkap ikan di sekitar rumpon tersebut. Nelayan pemilik rumpon dan nelayan lokal sudah memiliki aturan sendiri dimana pada pagi sampai sore hari nelayan lokal boleh mencari ikan di sekitar rumpon dan pada sore sampai malam hari kapal pukat cincin yang melakukan operasi penangkapan. Peta sebaran rumpon di perairan Kaur dapat dilihat pada Gambar 3.

Rumpon menciptakan suatu arena makan dan dimakan, mulai dengan tumbuhnya bakteri dan mikroalga ketika pertama kali rumpon dipasang. Selanjutnya makhluk renik tersebut bersama hewanhewan kecil lainnya akan menarik ikan-

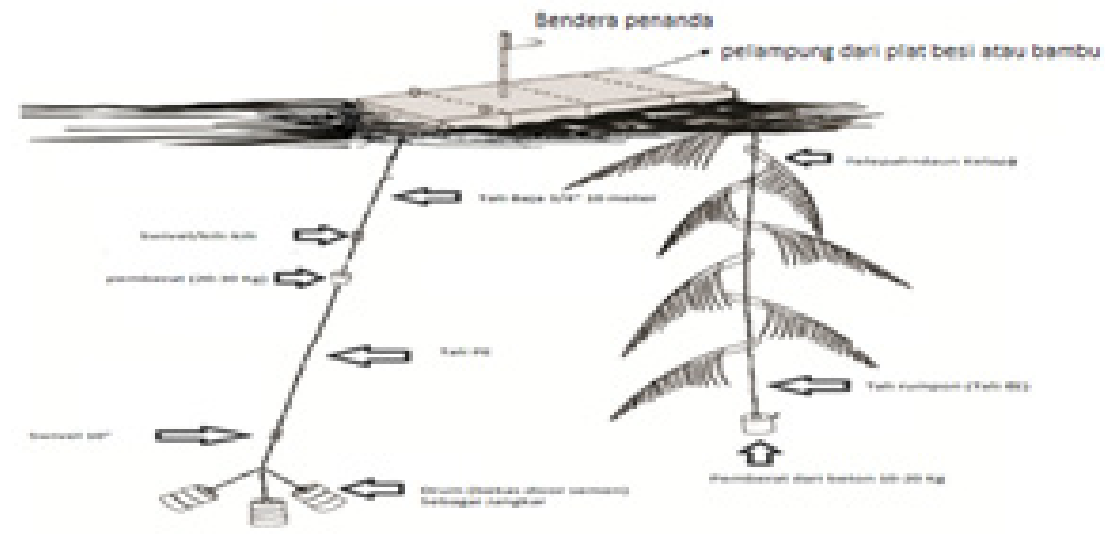

Gambar 2. Konstruksi rumpon

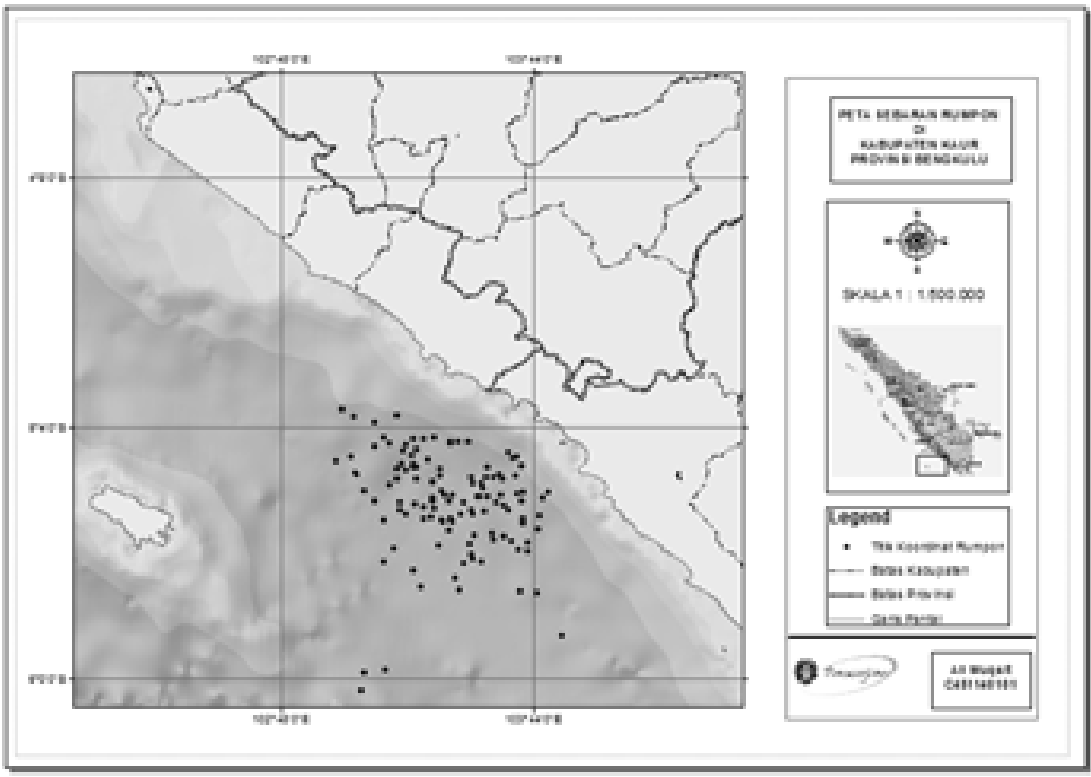

Gambar 3. Peta sebaran rumpon 
ikan pelagis kecil. Ikan-ikan ini akan memakan makhluk yang lebih kecil, pada giliran terakhir, ikan-ikan pelagis besar ada di sekitar rumpon karena adanya ikan-ikan pelagis kecil dan berusaha untuk memangsa. Ikan berkumpul dan tertarik disekitar rumpon diduga rumpon sebagai tempat berlindung juga mencari makan dalam arti luas (Subani 1972 dalam Yusfiandayani 2004)

Jenis ikan yang terkumpul di sekitar rumpon laut dalam adalah ikan pelagis ukuran besar seperti tuna (Thunnus spp), cakalang (Katsuwonus pelamis), tongkol (Auxis spp.), lemadang (Corryphaena spp.) dan marlin (Shomura dan Matsumoto 1982; Buckley et al. 1989; Wudianto 1991). Rumpon laut dalam ditujukan untuk mengumpulkan ikan pelagis besar seperti sehingga memudahkan dalam penangkapannya.

Pengoperasianalatbantu penangkapan rumpon diharapkan dapat meningkatkan efesiensi oleh karena biaya produksi dapat ditekan, waktu untuk mencari daerah penangkapan menjadi relatif singkat dan waktu yang tersedia untuk penangkapan (effective fishing time) meningkat. Ikan tuna sirip kuning (Thunnus albacares) yang berukuran besar dapat ditangkap dengan pancing tonda (Trollling) dan pancing ulur (hand line). Berdasarkan sifat dan tingkah laku ikan cakalang dan tuna (Thunnus albacares) di sekitar rumpon, diduga bahwa dengan menggunakan rumpon akan memberikan dampak positif terhadap hasil tangkapan, jumlah hari operasi dan biaya operasi (Bachtiar et al. 1987).
Pancing boya adalah sebutan pancing yang umum digunakan oleh nelayan Kaur dalam menangkap ikan tuna (Gambar 4). Pancing yang digunakan nelayan tuna Kabupaten Kaur ada 2 jenis yang pertama anco dan pancing boya. Anco terdiri dari pancing, senar, dan gulungan serta pemberat (Gambar 5). Panjang pancing yang digunakan $5 \mathrm{~cm}$, berdiameter $2 \mathrm{~mm}$. Senar yang digunakan nomor 150-200 ukuran kecil dengan panjang 50-100 meter. Anco ini digunakan untuk mencari umpan hidup seperti baby tuna, dan tongkol. Umpan yang digunakan dalam pengoperasian anco ini ialah umpan buatan seperti umpan tiruan berbentuk ikan. Nelayan tuna dalam mencari umpan tetap menghidupkan mesin kapal dengan kecepatan 5 knot, apabila pancing dimakan ikan kapal akan diperlambat, setelah umpan di dapatkan, umpan di masukan ke dalam wadah ember yang sudah berisi air untuk dibiarkan hidup dan sesegera mungkin dibawa ke lokasi sekitar rumpon untuk dijadikan umpan pada pancing boya.

Pancing boya sendiri adalah pancing modifikasi dari nelayan Kaur, dimana terdiri dari jerigen, pancing, dan senar. Tali yang digunakan adalah ukuran 150-200 dan panjangnya sekitar 100 meter serta mata pancing yang digunakan ialah no 1 atau 2 berukuran ukuran besar. Pengoperasian pancing boya menggunakan umpan hidup seperti baby tuna dan tongkol yang didapatkan sebelumnya dari anco, setelah umpan dikaitkan pancing boya kemudian di ulur sekitar 60-80 meter dan kemudian dibiarkan, setelah umpan dimakan maka jerigen sebagai pelampung akan berputar kemudian di ambil dan sembari ditahan dan diulur sampai ikan lemas dan naik ke permukaan.

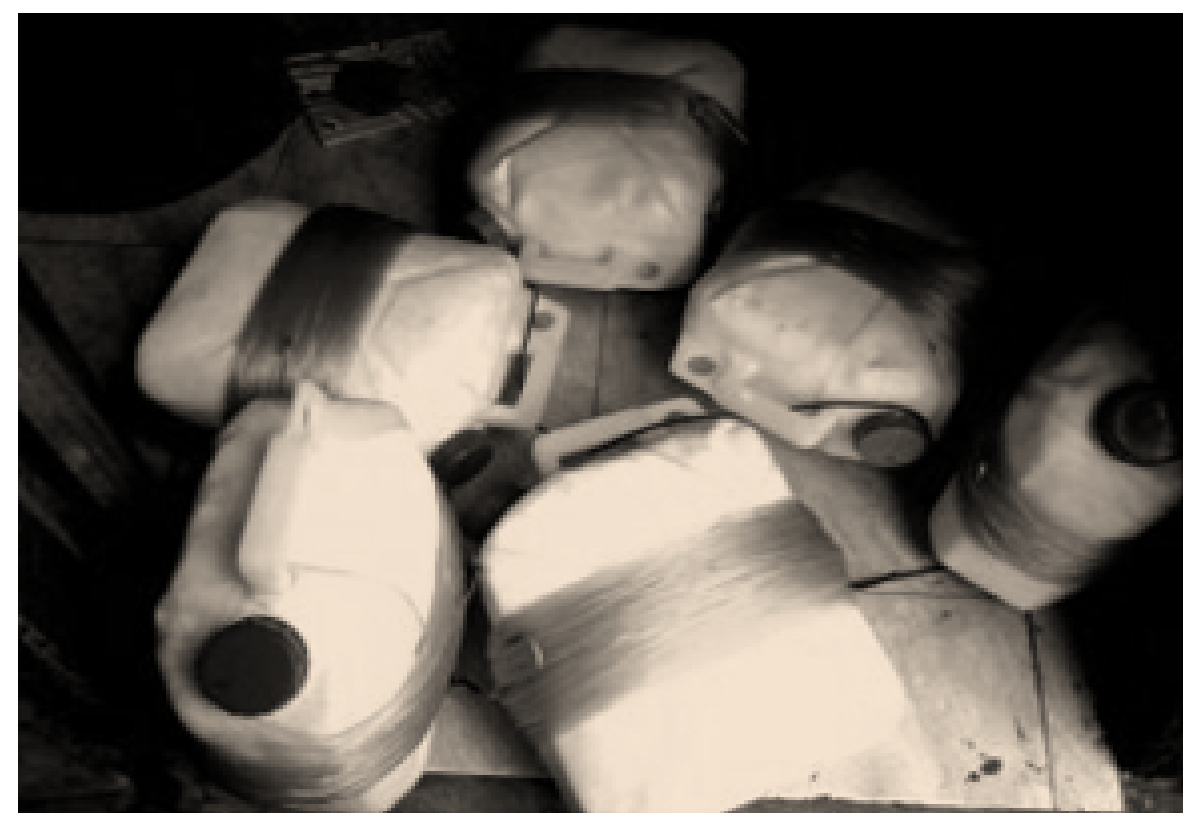

Gambar 4. Pancing boya 


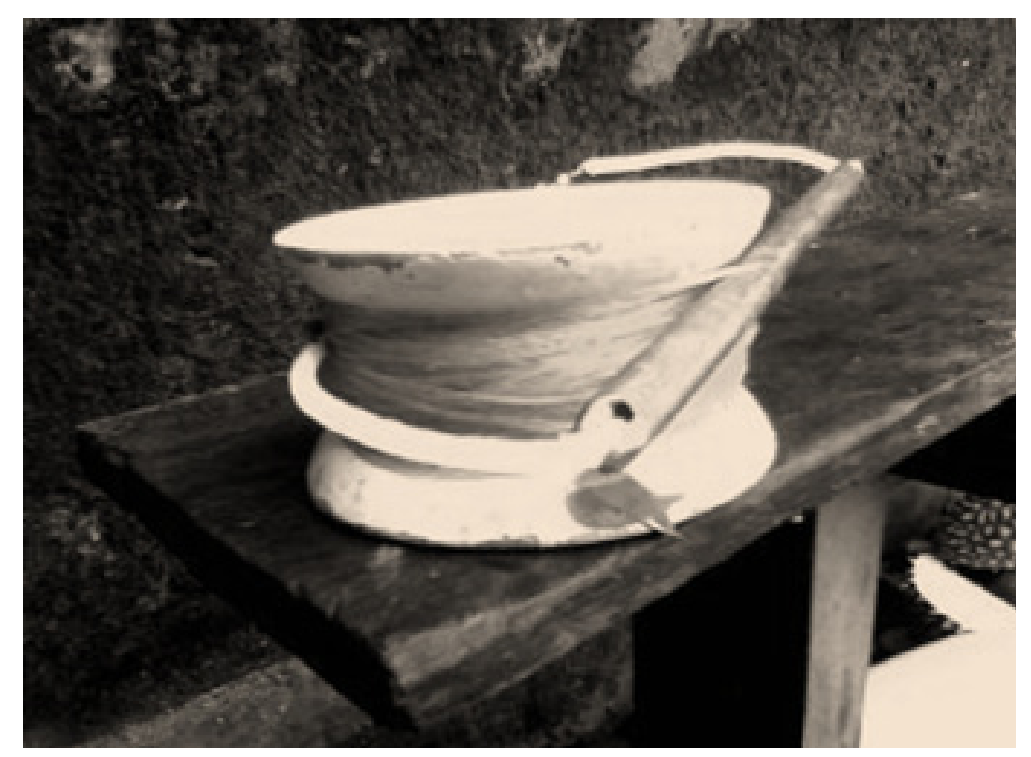

Gambar 5. Anco

\section{Hubungan panjang berat}

Sepanjang Januari 2015-Januari 2016 jumlah ikan yang tertangkap sebanyak 551 ekor tuna sirip kuning. Berdasarkan gambar 6 diketahui bahwa nilai b yang didapatkan lebih besar dari 3 dan hal ini berarti pola pertumbuhan ikan tuna bersifat allometrik positif, dengan kata lain pertambahan bobot lebih cepat dari pertambahan panjang. Hubungan panjang berat ikan tuna sirip kuning menunjukkan hubungan yang erat dengan koefisien korelasi ( $\mathrm{r}$ ) mendekati 1 yaitu sebesar 0.91 (Gambar 6) Koefisien b yang didapatkan sebesar 4.22 hal ini menunjukkan pertumbuhan ikan tuna sirip kuning di perairan Kaur memiliki pola allometrik positif atau pertambahan bobot lebih cepat dari pertambahan panjang (Tabel $1)$.

Hasil yang sama diperoleh oleh Manik (2007), pada ikan cakalang yang tertangkap di sekitar Pulau Seram dan Nusa laut serta sama juga dengan hasil penelitian oleh Merta (1989) dari hasil sampel ikan cakalang yang dikumpulkan dari TPI Bungus Sumatera Barat didapatkan juga hasil menyatakan bahwa pertumbuhan dari ikan cakalang yang didapatkan allometrik positif. Namun berbeda dengan hasil penelitian yang dilakukan oleh Telusa (1985) yang menyatakan ikan cakalang yang tertangkap di sebelah barat Sulawesi Tengah dimana memiliki pola pertumbuhan isometrik.

Berbedanya hasil analisis tersebut mungkin karena diferensiasi kisaran panjang ikan yang dianalisis cukup besar, selain karena pengaruh faktor-faktor biologis dan ekologis dari masing-masing perairan dimana ikan itu hidup. Sedangkan menurut Sumadhiharga (1991), menyatakan perbedaan nilai $b$ dipengaruhi oleh perbedaan musim dan tingkat kematangan gonad serta aktivitas penangkapan, karena aktivitas penangkapan yang cukup tinggi pada suatu daerah cukup mempengaruhi kehidupan dan pertumbuhan populasi ikan. Merta (1982) dalam Manik (2007) menyatakan karena kondisi lingkungan sering berubah dan atau kondisi ikannya berubah, maka hubungan panjang berat akan sedikit menyimpang dari hukum kubik $(b \neq 3)$. Sedangkan menurut Ricker 1973 dalam Kalayci et al. 2007, menyatakan bahwa perbedaaan tersebut diakibatkan oleh faktor ekologi seperti temperatur, ketersediaan makanan, kondisi pemijahan atau faktor-faktor lain seperti kelamin, umur, daerah dan waktu penangkapan serta kapal penangkapan yang digunakan. 


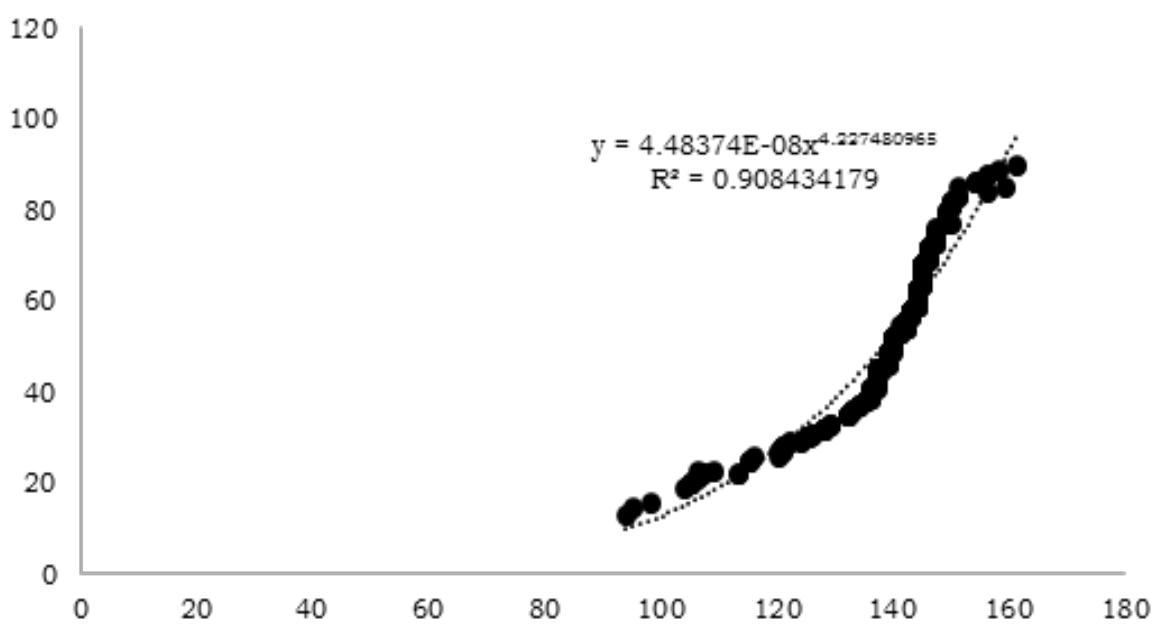

Gambar 6. Hubungan panjang berat

Tabel 2. Hasil uji-t hubungan panjang berat

\begin{tabular}{lcccccll}
\hline Jenis ikan & $\mathrm{R}^{2}$ & $\mathrm{a}$ & $\mathrm{b}$ & Thitung & Ttabel & Hasil & Keterangan \\
\hline $\begin{array}{l}\text { Ikan tuna sirip } \\
\text { kuning }\end{array}$ & 0.91 & -7.34 & 4.22 & 374.09 & 2.247 & Thit>Ttab & Allometrik positif \\
\hline
\end{tabular}

\section{Pengukuran frekuensi kejadian}

Kebiasaan makan pada ikan adalah kualitas dan kuantitas makanan yang dimakan oleh ikan. Kebiasaan dan cara makan adalah faktor penting yang menentukan keberhasilan mempertahankan eksistensi suatu organisme karena makanan menyediakan semua nutrisi yang diperlukan oleh organisme untuk tumbuh dan berkembang. Ikan jenis yellowfin tuna (Thunnus albacares) tergolong ikan jenis karnivora. Berdasarkan Gambar 7, organisme yang ditemukan dalam lambung ikan tuna sirip kuning antara lain sotong, ikan, cumi-cumi, kerang. Dari ke lima organisme yang ditemukan, organisme yang terbanyak adalah ikan. Sesuai dengan Manik (1998) jika diperhatikan seluruh komponen yang ada dapat dikatakan hanya 3 komponen utama yang merupakan makanan dari family scrombidae yaitu ikan, crustacea dan moluska.

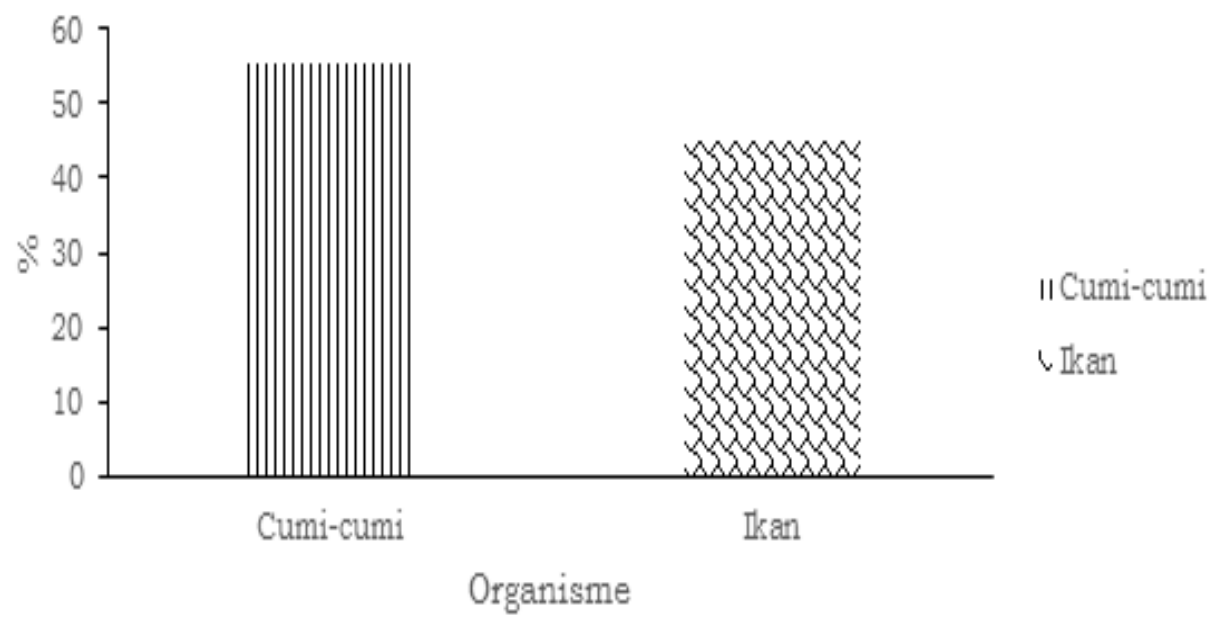

Gambar 7. Frekuensi kejadian 


\section{Pengukuran volumetrik}

Hasil pembedahan dari 30 lambung ikan tuna sirip kuning didapatkan lambung yang berisi berjumlah 24 dan yang kosong sejumlah 6 lambung. Berdasarkan pada Gambar 8, menunjukkan bahwa ikan tuna sirip kuning yang tertangkap diperairan Kaur memangsa beberapa organisme antara lain seperti cumi-cumi dan ikan jenis Vinciguerria poweriae. Hasil pengukuran volumetrik proporsi organisme cumi-cumi yang ditemukan paling banyak dari lambung ikan tuna sirip kuning dengan volume organisme sebesar $4.037 \mathrm{ml}$. Proporsi organisme terbanyak kedua adalah ikan jenis Vinciguerria poweriae dengan jumlah volume organisme sebanyak $1297 \mathrm{ml}$.

Hal ini sesuai dengan pernyataan Nuraini (2013), menyatakan bahwa organisme ikan menjadi makan ikan tuna sirip kuning yang tertangkap di perairan prigi Kabupaten Trenggalek. Effendie (2002) menyatakan bahwa perbedaan jumlah organisme makanan yang dimakan ikan terjadi karena perbedaan sebara organisme pada setiap wilayah dan faktor lainnya yang mepengaruhi kesukaan organisme perairan terhadap makananya antara lain adalah faktor penyebaran organisme makanan, faktor ketersediaan makanan, faktor pilihan dari ikan itu sendiri dan faktor lingkungan perairan.

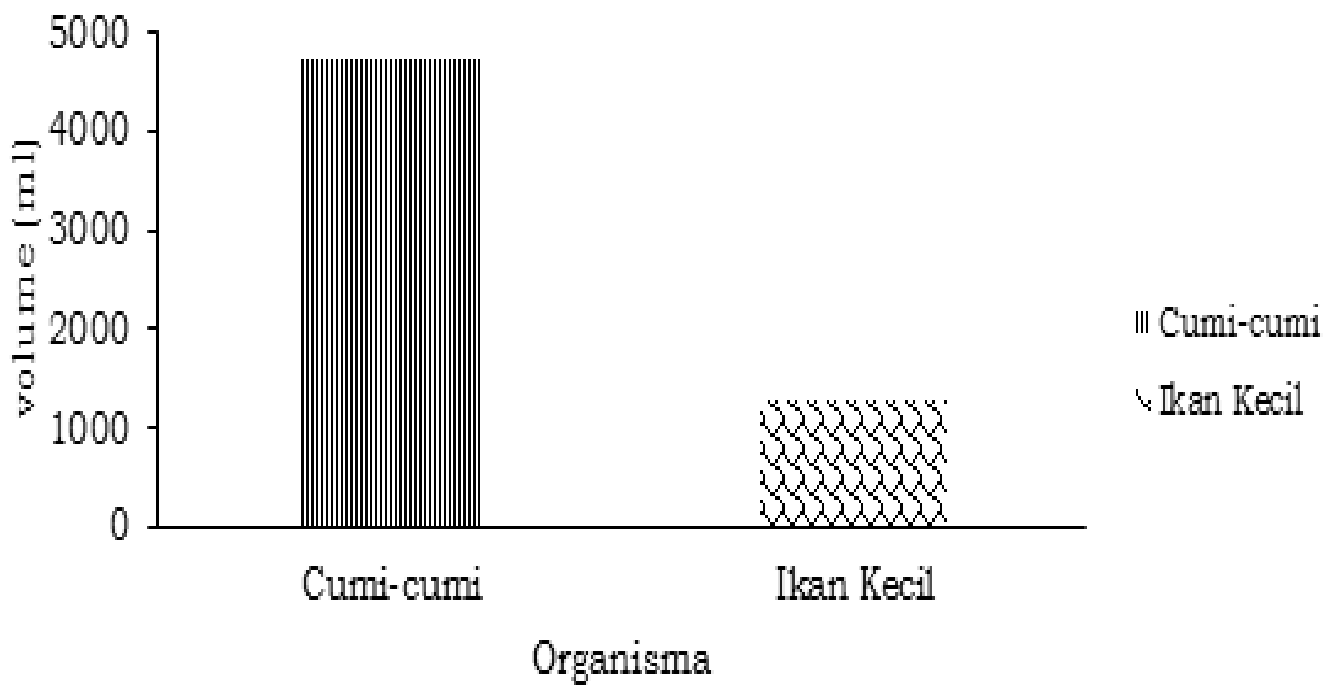

Gambar 8. Pengukuran volumetrik 


\section{Indeks preponderance}

Jenis makanan ikan tuna sirip kuning cukup bervariasi, hingga dapat diduga ikan yellowfin tuna tidak mempunyai preferensi dalam kebiasaan makan (feeding habit). Berdasarkan hasil analisis diketahui jenis makanan yang mendominasi dari isi lambung ikan tuna sirip kuning (Thunnus albacares) hasil tangkapan adalah cumicumi sebesar $81.77 \%$ dan ikan sebesar $18.23 \%$ dimana jenis ikan tersebut adalah Vinciguerria poweriae (Gambar 9). Menurut Biswas 1993, menyatakan ada 3 jenis ikan berdasarkan jenis makanannya, yaitu monopagik, stenopagik, dan europagic, dimana monopagic merupakan ikan yang hanya memakan satu jenis makanan, stenopagic merupakan ikan yang memakan beberapa jenis makanan yang berbeda, dan europagic adalah ikan yang memakan makananan yang sangata bervariasi. Dapat disimpulkan ikan tuna sirip kuning merupakan ikan yang tergolong stenopagic.

Hal ini sesuai dengan Malone et al. (2011) menyatakan dari hasil penelitiannya bahwa dari 31 ekor ikan tuna sirip kuning yang diteliti ditemukan beberapa organisme antara lain cephalopoda, stomatopoda, crustacea, ikan dan ikan yang tidak teridentifikasi. Menard et al. (2000) dalam Mardlijah (2005) dari analisis isi lambung ikan madidihang (Thunnus albacares) hasil tangkapan purse seine (pukat cincin) di perairan Teluk Guinea yang ditangkap disekitar rumpon. Jenis makanan ikan madidihang (Thunnus albcares) berukuran kurang dari $90 \mathrm{~cm}$ yang ditangkap di sekitar rumpon terdiri atas Vinciguerria nimbarria, cephalopoda, lain-lain, dan jenis tidak terdeterminasi (dominan). Sedangkan ikan madidihang (Thunnus albacares) berukuran lebih dari $90 \mathrm{~cm}$, jenis makanan didominasi oleh scrombidae 96\%. Ikan madidihang (Thunnus albacares) yang tertangkap tidak disekitar rumpon, jenis makanan ikan berukuran kurang dari $90 \mathrm{~cm}$ terdiri atas Vinciguerria nimbarria (dominan), cephalopoda, lain-lain, dan jenis tidak terdeterminasi. Untuk ikan berukuran lebih dari $90 \mathrm{~cm}$, jenis makanan terdiri atas scrombidae, cubiceps, dan lain-lain jenis tidak tereterminasi (dominan).

Gardief (2003) menemukan 37 famili dan 8 ordo invertebrate dalam lambung ikan madidihang (Thunnus albacares) dan jenis makanan lain meliputi lumba-lumba (Dolphin sp.), pilchard, anchovy (teri), ikan terbang (Hirundichtys oxycephalus), mackerel, lancetfish, cumi-cumi (Loligo $s p$ ), gurita, udang, lobster, dan jenis kepiting.

Hasil indeks preponderance yang didapat cumi-cumi merupakan makanan utama ikan tuna sirip kuning dan ini bias menjadi salah satu umpan terbaik yang dapat digunakan untuk penangkapan ikan tuna sirip kuning.

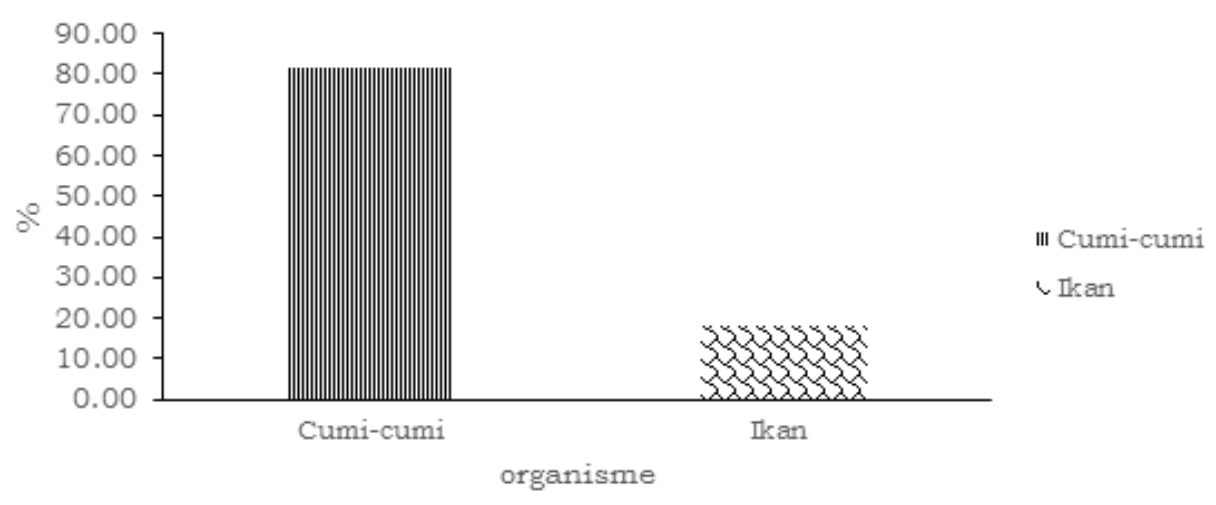

Gambar 9. Indeks preponderance 


\section{KESIMPULAN DAN SARAN}

\section{Kesimpulan}

Keragaan teknis yang digunakan untuk menangkap ikan madidihang adalah pancing boya yang terbuat dari jerigen 10 liter berisi busa dan tali pancing damil biru no 150-200 dengan mata pancing ukuran besar dan dioperasikan oleh 2 orang nelayan. Hasil analisis komposisi isi lambung diperoleh cumi-cumi sebesar $81.77 \%$ dan ikan poweriae $18.23 \%$ serta hubungan panjang berat didapatkan nilai $\mathrm{b}$ sebesar 4.22 bersifat allometrik positif.

\section{Saran}

Diperlukan kajian lanjutan untuk melihat pengaruh ukuran terhadap jenis dan ukuran mangsa yang dimakan.

\section{DAFTAR PUSTAKA}

Bachtiar G, Toha, Uktolseja J. 1987. Penandaan ikan cakalang dan madidihang di sekitar rumpon Teluk Tomini. Sulawesi Utara. JPPL. 43: 6774.

[BPS] Badan Pusat Statistik Kabupaten Kaur. 2013. Hasil sensus penduduk 2013 Kabupaten Kaur: BPS.

Biswas SP. 1993. Manual of methods in fish biology. South Asian Publisher, New Delhi, India.

Buckley RM, Itano DG, Buckley TW. 1989. Fish aggergation devices (FADs) enhancement of o f f s h o r e fisheries in American Samoa. Bulletin Marine Science 44(2):942-949.

Efendie MI. 1979. Metode biologi perikanan. Yayasan Dewi Sri. Bogor.

Efendie MI. 2002. Biologi perikanan. Yayasan Pustaka Nusantara. Yogyakarta.

Gunarso, W. 1985. Tingkah laku ikan dalam hubungannya dengan alat, metode, dan taktik penangkapan. Bahan Mata Ajaran Tingkah Laku Ikan. (tidak dipublikasikan)

Gardief S. 2003. Yellowfin tuna. 12 September 2003. Pukul 14.30 WIB. http:/www.flmnh.ufl.edu.

Hilborn R, Walters CJ. 1992. Quantitative fisheries stock assessment. choice, dynamics and uncertainty. Chapman and Hall. Inc. London. New York.

IPNLF. 2012. Ensuring sustainability of livebait fish, International Pole and line Foundation, London.

ISSF. 2009. International seafood sustainability foundation. Status of the world fisheries for tuna, Section A1 Introduction.

ISSF. 2014a. Long line international seafood sustainability foundation. http://iss foundation.org/longline/, accessed on 04-12-2014.

ISSF. 2014b. Pole and line international seafood sustainability foundation. http: / / iss-foundation.org/pole-and- line/, accessed on 04-12-2014.

Kagwade VN. 1967. Food and feeding habits of the horse mackerel, Caranx kalla (Cuv. \& Val). Indian Journal Fisheries. 14 (1 \& 2). 85-96

Kalayci F, Samsun N, Bilgin S, Samsun O. 2007. Lengthweight relationship of 10 caught by bottom trawl and midwater trawl from the middle Black Sea, Turkey. Tourkish Journal of Fisheries and Aqua tic Sciences 7: 3336.

Kepmen KP.RI, No Kep.30/MEN/ 2004. 2004. Tentang pemanfaatan dan pemasangan rumpon. KKP RI. 7 hal.

Lagler KF. 1956. Freshwater fishery biology. W.M. C. Brown Company. Dubugue. London. $422 \mathrm{hlm}$.

Malone MA, Buck KM, Moreno G, Sancho G. 2011. Diet of three large pelagic fishes associated with drifting fish aggregating devices (DFADs) in the western equatorial Indian Ocean. Animal Biodiversity and Conservation, 34.2: 287-294.

Manik N. 2007. Beberapa aspek biologi ikan cakalang (Katsuwonus pelamis) di perairan sekitar Pulau Seram Selatan dan Pulau Nusa Laut. Oseanologi dan Limnologi di Indonesia 33: 17-25.

Mardlijah S. 2005. Analisis isi lambung ikan cakalang (Katsuwonus pelamis) dan ikan madidihang (Thunnus albacares) yang didaratkan di Bitung, Sulawesi Utara. JPPI Vol 14. 137-235

Menard FB, Stequert A, Rubin M, Herera \& Marchal E. 2000. Food consumption of tuna in the Equatorial Atlantic Ocean. FAD Associated Versus Unassociated Schools. Aquatic Living Resources. (13). 233-240

Merta IGS. 1982. Studi pendahuluan makanan tingkat kematangan gonad ikan Cakalang, Katsuwonus pelamis (LINN.1758), Dari Perairan Sebelah Selatan Bali dan sebelah Barat Sumatera. Jur. Pen. Per. Laut 26 : 69 -74 .

Merta IGS. 1982. Dinamika populasi ikan cakalang, Katsuwonus pelamis Linnaeus 1758 (Pisces : Scombridae) dari perairan Sumatera Barat. Jurnal Penelitian Perikanan Laut 53:33-48

Mulyadi S. 2007. Ekonomi kelautan. PT. Raja Grafindo Persada. Jakarta.

Nuraini FA. 2013. Morfometri dan Komposisi Isi lambung Ikan Tuna Sirip Kuning (Thunnus albacares) yang Didaratkan di Pantai Prigi Jawa Timur. Journal of Marine Research. Semarang: 86-90.

Ricker WE. 1975. Computation and interpretation of biological statistic of fish populations. Fish. Res. Bd. Can. Bull. 191:382 pp.

Shomura RS, Matsumoto WM. 1982. Structure float as fish aggregating devices. U.S ept. Commerce. NOAA Tech. Memorandum. NMFS. NOAA- 
TM_NMFS-SWFC 22.9pp.

Sjafei DS, Rahardjo MF, Affandi R, Sulistiono. $\quad 1989 . \quad$ Ikhtiologi. Manajemen Sumber daya Perairan. Fakultas Perikanan. Institut Pertanian Bogor. Bogor. (tidak dipublikasikan)

Subani W. 1972. Alat dan cara penangkapan ikan di Indonesia. Jilid 1. Lembaga Penelitian Perikanan Laut, Jakarta.

Subani W, Barus HR. 1989. Alat Penangkap Ikan dan Udang Laut di Indonesia. Jurnal Penelitian Perikanan Laut Edisi Khusus 1988/1989. NO.50. 248 hal.

Sumadhiharga K. 1991. Struktur populasi dan reproduksi ikan momar merah (Decapterus ruselli) di teluk Ambon. Di dalam : BPPSL. Pusat penelitian dan Pengembangan Oseanologi-LIPI. Perairan Muluku dan Sekitarnya.

Stone R, Toribau L, Tolvanen S. 2009. Developing sustainable and equitable $\mathrm{P} / \mathrm{L}$ fisheries for skipjack. Greenpeace International, GPI Reference JN225.
Taunay PN. 2012. Studi Komposisi Isi Lambung dan Kondisi Morfometri Untuk Mengetahui $\mathrm{K}$ e b i a s a a $\mathrm{n}$ Makan Ikan Manyung (Arius thalassinus) Yang Diperoleh di Wilayah Semarang. Journal of Marine Research. Vol. 2, No. 1, Tahun 2013, (95): 1-9.

Telusa PS. 1985. Komposisi, morfometrik dan beberapa sifat meristik jenis-jenis ikan tuna yang tertangkap di Maluku Tengah. [Tesis]. Bogor: Sekolah Pasca Sarjana, Institut Pertanian Bogor. Bogor.

Wudianto. 1991. The use of payaos for tuna fisheries enhancement in the southeastpart of $\quad \mathrm{O} \mathrm{k} \mathrm{i} \mathrm{n} \mathrm{a} \mathrm{w} \mathrm{a}$ island. JPPL No.2 Th. 1991. 19pp.

Yusfiandayani R. 2004. "Studi Tentang Mekanisme Berkumpulnya Ikan Pelagis Kecil di Sekitar Rumpon dan Pengembangan Perikananya di Perairan Pasauran, Propinsi Banten." [Disertasi]. Bogor: Program Studi Teknologi Kelautan. Institut Pertanian Bogor. 